\title{
Not all minislings are alike
}

\author{
Ahmet Akin Sivaslioglu
}

Published online: 25 June 2014

(C) The International Urogynecological Association 2014

\section{Dear Editor,}

Randomized controlled trials (RCTs) on new operations are important, even with the omissions mentioned by Basu and Duckett [1] and those not mentioned: the absence of two adjustable tissue fixation system (TFS) minisling studies that contradict their thesis [2,3]. A TFS/TOT (transobturator tape) RCT by Sivaslioglu et al. in the Journal of Urology in 2010 reported the following: "TFS has a cure rate superior to that of the TOT, $83 \%$ vs $75 \%$ at 5 -year follow up ( $p 0.029)$. If subjective cure is added, the differential at 5 years is even larger at $89 \%$ vs $78 \%$ [2]. In 2009, Sekiguchi et al. reported a $90 \%$ cure rate in the $40 \%$ of patients who had intrinsic sphincter deficiency (ISD) [3].

These considerations aside, a major strength of the study was its performance by a single surgeon. In an IUJ editorial in 2006, Schuessler presented unassailable arguments about the invalidity of RCT surgical trials [4]. Sivaslioglu et al. emphasize the importance of a single surgeon experienced in both procedures performing both arms of the RCT. This helps diminish one important variable, differing skills [2].

It is important for a clinical surgeon to know what cure rate to expect in the first 40 cases. Inclusion of the learning curve in the results is perhaps the singular defining strength of this paper [1]. Despite the ethical (patients) and scientific considerations (flawed data) in omitting learning curves, I know of no minisling papers other than the studies by Basu and Duckett, Sivaslioglu et al., and Sekiguchi et al. where the learning curve results were included.

A reply to these comments can be found at doi: 10.1007/s00192-014$2440-8$

A. A. Sivaslioglu ( $\bowtie)$

Katip Çelebi University, Atatürk Training and Research Hospital,

Obstetrics and Gynecology Clinics, Seferihisar Caddesi 2730 Sokak, Ege Park Konaklari No.53/H, Yelki, Güzelbahçe, İzmir, Turkey

e-mail: akinsivaslioglu@gmail.com
It is regrettable that the Miniarc was not tested for ISD, cure of ISD being perhaps the acid test for midurethral sling effectiveness.

The superior cure rate of the TVT vs Miniarc may have to do with the fact that first the tape is placed around the urethra and then tightened. The Miniarc has to perform both actions simultaneously. The tapes are pushed against the elastic tissues of the urethra and the paraurethral tissues. Allowance has to somehow be made for elastic restoration of the tissues. This can only be estimated. However, the TFS minisling also has two separate actions: the anchors are placed, then the tape is precisely tightened via an adjustable system at the base of the anchor, like the TVT. This may explain the ability of TFS to cure ISD.

The concluding statements, which mainly concern nonadjustable slings are wise, to which one may add "inclusion of learning curve data."

Conflict of interest None.

\section{References}

1. Basu M, Duckett J (2013) Three-year results from a randomised trial of a retropubic mid-urethral sling versus the miniarc single incision sling for stress urinary incontinence. Int Urogynecol J 24(12):2059-2064. doi:10.1007/s00192-0132125-8

2. Sivaslioglu AA, Unlubilgin E, Aydogmus S et al (2012) A prospective randomized controlled trial of the transobturator tape and tissue fixation mini-sling in patients with stress urinary incontinence: 5-year results. J Urol 188:194-199

3. Sekiguchi Y, Kinjyo M, Inoue H et al (2009) Outpatient mid urethral tissue fixation system sling for urodynamic stress urinary incontinence. J Urol 182:2810-2813

4. Schuessler B (2006) Evidence-based medicine in surgery for urinary incontinence: none is so blind as the double blind. Int Urogynecol J 17: 312-314 